\title{
Effect of photoperiod on the cultural morphology of Rhizoctonia solani isolates of maize from Yogyakarta and Central Java, Indonesia
}

\author{
SRI WAHYUNI BUDIARTI ${ }^{1,2,}$, RUDY LUKMAN ${ }^{3}$, CHRISTANTI SUMARDIYONO ${ }^{4}$, ARIF WIBOWO $^{4}$, \\ ACHMADI PRIYATMOJO ${ }^{4, \vee \varphi}$ \\ ${ }^{1}$ Program of Agricultural Sciences, Faculty of Agriculture, Universitas Gadjah Mada. Jl. Flora No. 1, Bulaksumur, Sleman 55281, Yogyakarta, Indonesia. \\ "email: sriwahyuni.budiarti@gmail.com. \\ ${ }^{2}$ Assessment Institutes for Agricultural Technology of Yogyakarta. Jl. Stadion Maguwoharjo No. 22, Sleman 55584, Yogyakarta, Indonesia. \\ ${ }^{3}$ Department of Biotechnology PT. Bisi International, Tbk, Kediri 64175, East Java, Indonesia. \\ ${ }^{4}$ Departement of Crop Protection, Faculty of Agriculture, Universitas Gadjah Mada. Jl. Flora No. 1, Bulaksumur, Sleman 55281, Yogyakarta, Indonesia. \\ Tel./fax.: +62-274-523926. ${ }^{*}$ email: priyatmojo@ugm.ac.id.
}

Manuscript received: 27 March 2019. Revision accepted: 29 May 2019.

\begin{abstract}
Budiarti SW, Lukman R, Sumardiyono C, Wibowo A, Priyatmojo A. 2019. Effect of photoperiod on the cultural morphology of Rhizoctonia solani isolates of maize from Yogyakarta and Central Java, Indonesia. Biodiversitas 20: 2028-2038. Banded leaf and sheath blight (BLSB) caused by Rhizoctonia solani Kuhn is a significant constraint of maize production in Indonesia, especially within the last several years. $R$. solani is an important soil-borne necrotrophic fungal pathogen which is known to be sensitive to different environmental conditions. The differential response of fungi to light and dark is important to study, especially of those cau sing disease to crop plant as it helps to reveal the factors regulating the pathogenicity of the fungus. This study aims to determine the effect of light duration on the mycelial development and sclerotia formation of $R$. solani isolates obtained from different locations in Yogyakarta Special Region and Central Java, Indonesia. Ten isolates of $R$. solani collected from different geographic regions in Yogyakarta Special Region, and Central Java from maize (nine isolates) and rice (one isolate) were exposed to three different light conditions: $12 \mathrm{~h}$ alternating light/dark, continuous darkness, and continuous light. Cultural morphology and sclerotial characteristics were recorded for each isolate. All isolates revealed great diversity in terms of cultural and morphological characteristics after exposure to three different light conditions. Under complete darkness, the mycelial growth phase was extended, and a fluffy mass of mycelia was produced. All isolates showed abundant growth under the $12 \mathrm{~h}$ alternating light/dark condition than under the continuous dark and continuous light conditions. Sclerotia were initiated earlier under the $12 \mathrm{~h}$ alternating light/dark condition than under other conditions. The $12 \mathrm{~h}$ alternating light/dark condition also induced number and heavier weight of sclerotia compared with those produced under the continuous light and continuous dark conditions. The modifications in light condition exert a significant impact on some $R$. solani isolates.
\end{abstract}

Keywords: Banded leaf and sheath blight, mycelia, Rhizoctonia solani, sclerotia, variability

\section{INTRODUCTION}

Banded leaf and sheath blight (BLSB), one of the most important diseases of maize (Zea mays) worldwide, is caused by Rhizoctonia solani. BLSB causes severe yield losses in crops of high economic value (Lin et al. 2008; Gao et al. 2014; Dai et al. 2017). In recent years, BLSB epidemics have been reported in India, Sri Lanka, Sierra Leone, Ivory Coast, Nigeria, England, USA (Arkansas), Venezuela, Bhutan, Japan, Korea, Malaysia, Myanmar, Nepal, Pakistan, Philippines, Southern China, Thailand, Vietnam, and Indonesia (Sharma et al. 2002; Hooda et al. 2015; Zhou et al. 2016).

Grain yield losses caused by this disease have been reported to range from $11 \%$ to $40 \%$ in India and $100 \%$ in susceptible cultivars grown under warm and high humid regions in Southwest China, where the conditions are favorable for the pathogens (Izhar and Chakraborty 2013; Gao et al. 2014). In Indonesia, reports on the yield loss of corn due to BLSB are limited. The disease was recorded causes yield losses of up to $100 \%$ by Sudjono (1995). The research conducted by Soenartiningsih et al. (2006) showed that the highest disease intensity was observed in two different cultivars of maize inoculated by $R$. solani. The intensity for Wisanggeni variety was $70.05 \%$, while for GM 30 line was $73.79 \%$. Soenartiningsih (2007) reported BLSB might be found in many maize cultivations in South Sulawesi, Malang, and Blitar. This disease was also reported in Palu Valley, especially Donggala, Central Sulawesi. The infected plant seemed that higher disease incidence occurred during the rainy rather than the dry season (Muis et al. 2010). Field trials of Anoman variety of maize showed that intensity of BLSB disease was $83.5 \%$ (Djaenuddin et al. 2017).

The fungus can survive in the form of sclerotia or hyphae in the soil or remain on infected plants (Soenartiningsih et al. 2015). Various biotic and abiotic factors directly or indirectly influence the development of sclerotia (Maurya et al. 2010). The vegetative growth and morphogenesis of fungi, such as hyphal development, sporulation, and sclerotial formation, are affected by nutrients and physical factors, such as temperature, water or humidity, $\mathrm{pH}$ and light (Moromizato et al. 1983). The pathogen is adapted in the different agro-ecological region 
having different light intensity and light duration (Mishra et al. 2014a).

Effect of photoreaction on filamentous fungi has been reported by Miller and Liberta (1977), Degli and Russo (1984), Lokesha and Somashekar (1988), Hatakeyama et al. (2007), Maurya et al. (2010), Dutta et al. (2012), Mishra et al. (2014b), and Patidar et al. (2017). Miller and Liberta (1977) showed that some effect of light on morphogenesis in Sclerotium rolfsii Sacc. Degli and Russo (1984) reported that blue light triggered various developmental, morphological, and physiological responses in Neurospora crassa. Lokesha and Somashekar (1988) studied the influence of light on growth pattern and sclerotial formation of $R$. solani isolate from maize. Hatakeyama et al. (2007) provided the first report that Aspergillus oryzae perceived and responded to various types of light (white, red, and blue). The effect of air and light on sclerotial development and basidiospore formation in Sclerotium rolfsii was studied by Maurya et al. (2010). The effect of different light intensities and light duration patterns on the growth and sclerotial development of an isolate of $R$. solani from rice (Dutta et al. 2012). Mishra et al. (2014b) found that the effect of light and dark periods on colony characteristics, sclerotia initiation, and their number for fungal pathogen $R$. solani f.sp. sasakii. Assessing the effect of the varied wavelength of light on the growth and sclerotial formation of $R$. solani Kuhn, also studied by Patidar et al. (2017). Mishra et al. (2014b) reported that ten isolates of $R$. solani f. sp. sasakii collected from maize in India produce variable culture morphologies after exposure to three different light conditions.

In Indonesia, a study on collecting maize isolates of $R$. solani from the varied geographical location is not available. The review of the literature revealed no studies on the effect of photoperiod on the mycelial development and sclerotial formation of $R$. solani isolates from Indonesia have yet been reported. The correlation between light quality and sclerotial development presents important implications for the build-up of $R$. solani inoculum in the soil, which may affect disease severity and long-term cultivation in affected regions. Mycelia and sclerotia can emerge and develop on plant debris, enabling inoculum to survive in the soil such as freezing, desiccation, microbial attack, as well as in seeds, from season to season. If the state of the environment is conducive, this resting cell will grow into hypha or mycelium (Ritchie et al. 2009; Nuraini et al. 2017).

This study aims to determine the effect of light duration on the mycelial development and sclerotial formation of $R$. solani isolates from different locations in Yogyakarta Special Region and Central Java, Indonesia

\section{MATERIALS AND METHODS}

\section{Study area}

Ten isolates of $R$. solani were collected from different parts of Yogyakarta Special Region and Central Java of Indonesia. Nine $R$. solani isolates infecting maize (SLM1, SLM2, SLM3, BYL1, BYL2, KLT, KRY, PTI, BLR) and one from rice (NGW) (Figure 1).

\section{Isolation of $\boldsymbol{R}$. solani}

The infected leaf sheath $\left(5 \mathrm{~mm}^{2}\right)$ and sclerotia of the fungus from each infected sample were clean in sterilize distilled water and surface sterilized in $0.5 \%$ sodium hypochlorite solution for 30-60s, washed three times with sterilized distilled water, dried on filter paper and placed on potato dextrose agar (PDA) medium (OXOID, made in the United Kingdom) The plate was at $27-30{ }^{\circ} \mathrm{C}$ for $2-3$ days incubated (Lal et al. 2014; Singh et al. 2018). Pure cultures were obtained by re-culture from hyphal tips and maintained on PDA (Priyatmojo et al. 2001; Bintang et al. 2017). Mycelial discs (Ø $5 \mathrm{~mm}$ ) of 5-d-old cultures of each isolate were transferred to PDA and incubated for four weeks at $30 \pm 2{ }^{\circ} \mathrm{C}$ (Singh et al. 2014).

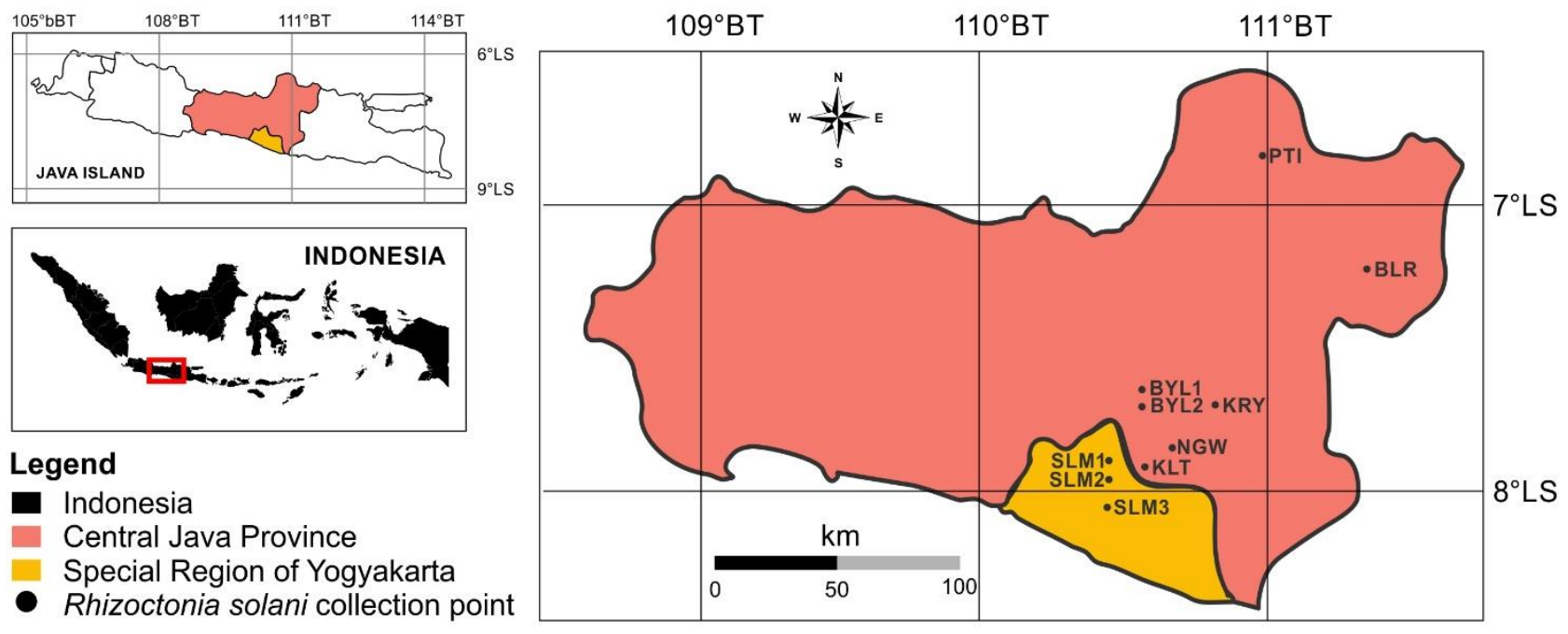

Figure 1. Origin of Rhizoctonia solani isolates collected from different locations in Yogyakarta and Central Java of Indonesia 


\section{Light treatments}

To study the influence of light, three growth incubators were constructed, each with white light (PHILIPS Lifemax; TLD 18 W/54-765; Indonesia). Two incubators were set at $24 \mathrm{~h}$ of light, and one incubator was set at $12 \mathrm{~h}$ light, controlled by an automatic timer set to real time. All isolates were exposed to three different light conditions, namely $12 \mathrm{~h}$ alternating light/dark, $24 \mathrm{~h}$ continuous darkness, and $24 \mathrm{~h}$ continuous light, and incubated at $30 \pm 2$ ${ }^{\circ} \mathrm{C}$. All plates were placed at equidistant from the light source. Artificial darkness was created by wrapping the petri dish (90 mm diameter) with double-layered aluminum foil. Each treatment consisted of 3 replicates (Lee et al. 2010; Mishra et al. 2014b).

\section{Culture morphology characteristics}

Radial growth, colony texture, colony color, and growth pattern were recorded for each culture. The radial growth was obtained by measuring the colony diameter after every $24 \mathrm{~h}$ of growth for four days. For that, two perpendicular lines are made on the bottom side of the petri dish. These lines are used to measure the means diameter of the colony growth of each isolate. The mean colony growth was then calculated from the three replicates of each treatment. Based on the colony growth, each isolate was classified into three groups, i.e., fast (48 h), medium (72 h), and slow (96 h or more) growing (Debbarma and Dutta 2015; Singh et al. 2018).

The colony texture and growth pattern were recorded after $10 \mathrm{~d}$ of incubation. Hyphal growth patterns were recorded by visual observation and classified as abundant (aerial mycelium obscured the surface mycelium and touched the cover of the Petri dish), moderate (aerial mycelium obscured the surface mycelium without touching the cover), or slight (aerial mycelium did not obscure the surface mycelium) (Lal and Kandhari 2009). Colony color was observed from the lower side of culture plate and compared with the Munsell Soil Colour chart after four weeks incubation (Singh et al. 2014).

\section{Sclerotial characteristics}

The time required for initiation of sclerotial formation, the distribution pattern of produced sclerotia, color, number, and weight of each $R$. solani isolate were recorded four weeks after incubation. Based on sclerotia number per plate, isolates were categorized as poor (no sclerotia), fair (1-10), moderate (11-20), good (21-40), very good (41-60), or excellent (>60) (Mishra et al. 2014a).

\section{Data analysis}

The experiment was performed in two factors, different photoperiod and isolates arranged in Completely Randomized Design, in three replications. The recorded data were objected to analysis of variance (ANOVA) and mean comparisons were done by using Fisher's LSD test at $5 \%$ of the significance level by using statistical software SAS V9.2.

\section{RESULTS AND DISCUSSION}

\section{Culture morphology characteristics}

Isolates from maize and rice showed variations in cultural and morphological characteristics (Table 1).

\section{Radial growth}

All isolates incubated under the $24 \mathrm{~h}$ continuous dark condition required over $96 \mathrm{~h}$ to complete radial growth. Under the $24 \mathrm{~h}$ continuous light condition, SLM3, and NGW needed 96 h to complete radial growth, while SLM1, SLM2, BYL1, BYL2, KLT, KRT, PTI, and BLR required over $96 \mathrm{~h}$. Under the $12 \mathrm{~h}$ alternating light/dark condition, all isolates grew slowly. SLM3, BYL1, KLT, KRY, and NGW required $96 \mathrm{~h}$ to complete radial growth, while SLM1, SLM2, BYL2, PTI, and BLR required over $96 \mathrm{~h}$ to complete radial growth (Figure 2). The rice isolates NGW grew faster under the $24 \mathrm{~h}$ continuous light and $12 \mathrm{~h}$ alternating light/dark conditions than under the $24 \mathrm{~h}$ continuous dark condition.

\section{Colony texture}

The colony texture was categorized as either cottony or cottony fluffy. Under the $24 \mathrm{~h}$ continuous dark condition, eight isolates showed cottony mycelium while isolates PTI and BLR produced cottony fluffy mycelia. Only BYL1, KLT, and NGW showed cottony fluffy mycelia under the $24 \mathrm{~h}$ continuous light condition; all other isolates showed cottony colonies. Similarly, under the $12 \mathrm{~h}$ alternating light/dark condition, BYL1, KLT, and NGW showed cottony fluffy mycelia, whereas the other isolates showed cottony colonies.

\section{Colony color}

Based on the colony pigmentation observed under the $24 \mathrm{~h}$ continuous dark condition, ten isolates were classified into six groups, namely, dark yellowish brown, olive yellow, pale yellow, light olive-brown, light yellowish brown, and dark brown. Under the $24 \mathrm{~h}$ continuous light condition, four colony colors, namely, white, pale yellow, yellowish brown, and dark yellowish brown, were observed. Under the $12 \mathrm{~h}$ alternating light/dark condition, three colony colors, namely, white, pale yellow, and olive yellow, were found.

\section{Growth pattern}

All isolates were categorized into two groups based on growth pattern: abundant or moderate. Under the $24 \mathrm{~h}$ continuous dark condition, the 10 isolates showed moderate growth. Only two isolates, SLM3 and BYL2, showed abundant growth under the $24 \mathrm{~h}$ continuous light condition; all other isolates showed moderate growth. By comparison, eight isolates showed abundant growth while two isolates showed moderate growth under the $12 \mathrm{~h}$ alternating light/dark condition. 


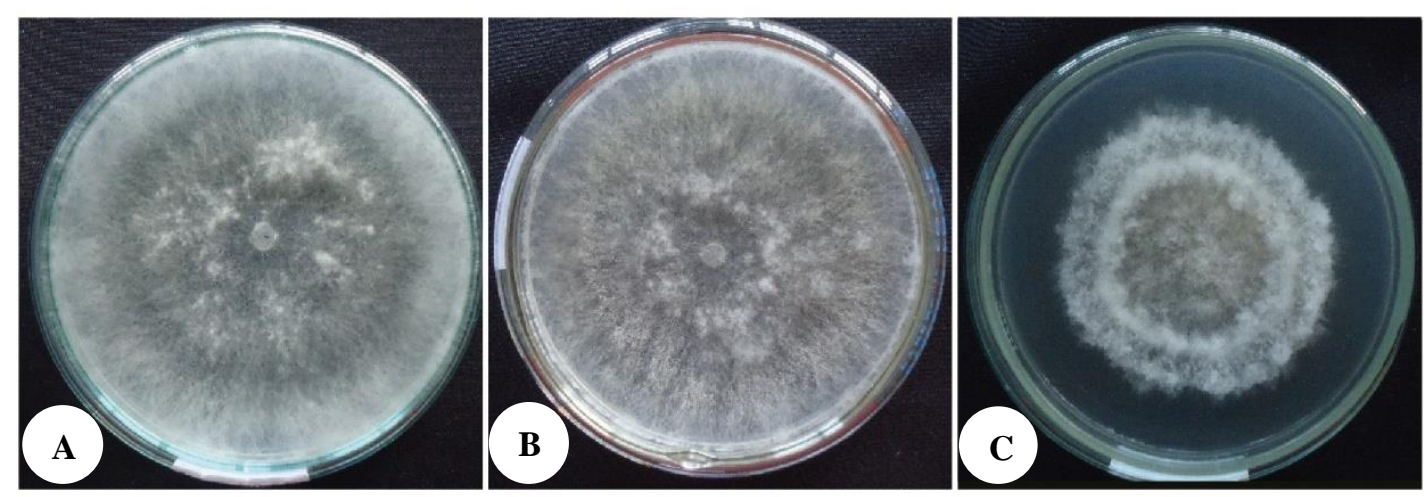

Figure 2. The comparison of radial growth of Rhizoctonia solani SLM3 at 96 h. A. 12 h alternating light/dark (full growth); B. 24 h continuous light (full growth); C. 24 h continuous darkness (incomplete growth)

\section{Sclerotial characteristics}

Tables 2, 3, and 4 show the effect of photoperiod on the sclerotial characteristics of $R$. solani.

\section{Time required for sclerotial formation}

The time required for sclerotial formation: Time for sclerotial formation ranged from 5-9 d under the $12 \mathrm{~h}$ alternating light/dark condition to $8-19 \mathrm{~d}$ under the $24 \mathrm{~h}$ continuous dark condition. In the $24 \mathrm{~h}$ continuous light condition, sclerotial formation was delayed, and the BYL1 isolate required a maximum of $26 \mathrm{~d}$ to form sclerotia. PTI and BLR did not produce any sclerotia until the 30th day under this light condition.

\section{Distribution pattern}

The distribution pattern of sclerotia on PDA under the $24 \mathrm{~h}$ continuous dark condition ranged from irregular (SLM1, BYL1, BYL2, KLT, KRY, NGW) to sub-central (SLM2) or central-sub-central (SLM3). Under the $24 \mathrm{~h}$ continuous light condition, the pattern of distribution of sclerotia was peripheral (BYL1, KLT, KRY, NGW), irregular (SLM2, SLM3), and sub-central-peripheral (SLM1, BYL2). In the $12 \mathrm{~h}$ alternating light/dark condition, peripheral (SLM2, SLM3, KRY, KRY) to irregular (SLM1, NGW) and, rarely, sub-central-peripheral (BYL1) and sub-central (NGW) patterns were observed (Figure 3).

\section{Color and type of sclerotia}

All 10 isolates of $R$. solani showed no variation in, the color of sclerotia produced. The isolates PTI and BLR did not produce any sclerotia. The remaining eight isolates of $R$. solani showed dark brown sclerotia. The results showed that there were two variations in sclerotial type of $R$. solani isolates under three different light conditions, i.e., micro and macro (Figure 4).
Number and weight of sclerotia

The total numbers of sclerotia are summarized in Table 4. Significant variations (at $\mathrm{P}<0.05$ ) in the number of sclerotia were found among ten $R$. solani isolates affected by three different light conditions. A significant interaction between light duration and isolates was also noted. Under the $24 \mathrm{~h}$ continuous dark condition, only a limited number of sclerotia (fair) were produced by SLM2, BYL1, KRY, and NGW. Isolate SLM1 revealed moderate sclerotial production, while SLM2, BYL1, and KRY showed good sclerotial production. Under the $24 \mathrm{~h}$ continuous light condition, only isolate BYL1 produced a limited number of sclerotia (fair). Isolates SLM3 and KRY showed moderate sclerotial production, while SLM1, KLT, and NGW revealed good sclerotial production. Isolates SLM2 and BYL2 demonstrated very good and excellent sclerotial production, respectively. Isolates yielded higher sclerotial numbers under the artificial $12 \mathrm{~h}$ alternating light/dark condition than under the $24 \mathrm{~h}$ continuous dark condition. Two isolates, SLM1 and SLM3, showed excellent sclerotial production, while BYL1, BYL2, KLT, KRY, and NGW demonstrated very good sclerotial production. Only isolate, SLM2, revealed good sclerotial production under the $12 \mathrm{~h}$ alternating light/dark condition. Two isolates, PTI and BLR, did not produce sclerotia (Figure 5).

The weight of sclerotia is summarized in Table 5 . Significant variations (at $\mathrm{P}<0.05)$ in the weight of sclerotia were found among ten $R$. solani isolates affected by three different light conditions. A significant interaction between light duration and isolates was also noted. Diverse sclerotia weights according to the light condition were observed. The average weight of sclerotia under the $12 \mathrm{~h}$ alternating light/dark condition was higher (0-177.80 mg) compared with those obtained under the $24 \mathrm{~h}$ continuous light (0$94.37 \mathrm{mg}$ ) and $24 \mathrm{~h}$ continuous dark (0-36.67 mg) conditions. 
Table 1. Effect of photoperiod on the cultural and morphological characteristics of different Rhizoctonia solani isolates

\begin{tabular}{|c|c|c|c|c|c|c|c|c|c|c|c|c|}
\hline \multirow[b]{2}{*}{$\begin{array}{l}\text { Code } \\
\text { isolate }\end{array}$} & \multicolumn{4}{|c|}{24 h dark } & \multicolumn{4}{|c|}{24 h light } & \multicolumn{4}{|c|}{12 h dark/12 h light } \\
\hline & $\begin{array}{l}\text { Complete } \\
\text { radial } \\
\text { growth }(h)\end{array}$ & Colony color & $\begin{array}{l}\text { Colony } \\
\text { texture }\end{array}$ & $\begin{array}{l}\text { Growth } \\
\text { pattern }\end{array}$ & $\begin{array}{l}\text { Complete } \\
\text { radial } \\
\text { growth }(h)\end{array}$ & Colony color & Colony texture & $\begin{array}{l}\text { Growth } \\
\text { pattern }\end{array}$ & $\begin{array}{l}\text { Complete } \\
\text { radial } \\
\text { growth (h) }\end{array}$ & Colony color & $\begin{array}{l}\text { Colony } \\
\text { texture }\end{array}$ & $\begin{array}{l}\text { Growth } \\
\text { pattern }\end{array}$ \\
\hline SLM1 & 264 & Dark yellowish brown & Cottony fluffy & Moderate & 120 & Yellowish brown & Cottony & Moderate & 120 & Pale yellow & Cottony & Abundant \\
\hline SLM2 & 312 & Olive yellow & Cottony fluffy & Moderate & 144 & Pale yellow & Cottony & Moderate & 120 & Pale yellow & Cottony & Abundant \\
\hline SLM3 & 168 & Light olive brown & Cottony fluffy & Moderate & 96 & White & Cottony & Abundant & 96 & White & Cottony & Abundant \\
\hline BYL1 & 480 & Olive yellow & Cottony fluffy & Moderate & 120 & Pale yellow & Cottony fluffy & Moderate & 96 & Pale yellow & Cottony fluffy & Abundant \\
\hline BYL2 & 240 & Dark brown & Cottony fluffy & Moderate & 120 & Dark yellowish brown & Cottony & Abundant & 120 & Pale yellow & Cottony & Abundant \\
\hline KLT & 528 & Dark yellowish brown & Cottony fluffy & Moderate & 120 & Pale yellow & Cottony fluffy & Moderate & 96 & White & Cottony fluffy & Abundant \\
\hline KRY & 240 & Light yellowish brown & Cottony fluffy & Moderate & 120 & Pale yellow & Cottony & Moderate & 96 & White & Cottony & Abundant \\
\hline PTI & 480 & Dark brown & Cottony & Moderate & 144 & Dark yellowish brown & Cottony & Moderate & 144 & Olive yellow & Cottony & Moderate \\
\hline BLR & 288 & Pale yellow & Cottony & Moderate & 144 & White & Cottony & Moderate & 168 & White & Cottony & Moderate \\
\hline NGW & 480 & Dark yellowish brown & Cottony fluffy & Moderate & 96 & White & Cottony fluffy & Moderate & 96 & Pale yellow & Cottony fluffy & Abundant \\
\hline
\end{tabular}

Table 2. Effect of photoperiod on sclerotia characteristics of different Rhizoctonia solani isolates

\begin{tabular}{|c|c|c|c|c|c|c|c|c|c|c|c|c|}
\hline \multirow[b]{2}{*}{$\begin{array}{l}\text { Code } \\
\text { isolate }\end{array}$} & \multicolumn{3}{|c|}{24 h dark } & \multicolumn{5}{|c|}{24 h light } & \multicolumn{3}{|c|}{24 h dark/12 h light } & \multirow[b]{2}{*}{$\begin{array}{c}\text { Type of } \\
\text { sclerotia }\end{array}$} \\
\hline & $\begin{array}{c}\text { Time of } \\
\text { sclerotia } \\
\text { formation } \\
\text { (days) }\end{array}$ & $\begin{array}{c}\text { Distribution } \\
\text { pattern }\end{array}$ & $\begin{array}{l}\text { Color of } \\
\text { sclerotia }\end{array}$ & $\begin{array}{c}\text { Type of } \\
\text { sclerotia }\end{array}$ & $\begin{array}{c}\text { Time of } \\
\text { sclerotia } \\
\text { formation } \\
\text { (days) }\end{array}$ & $\begin{array}{c}\text { Distribution } \\
\text { pattern }\end{array}$ & $\begin{array}{l}\text { Color of } \\
\text { sclerotia }\end{array}$ & $\begin{array}{c}\text { Type of } \\
\text { sclerotia }\end{array}$ & $\begin{array}{c}\text { Time of } \\
\text { sclerotia } \\
\text { formation } \\
\text { (days) }\end{array}$ & $\begin{array}{c}\text { Distribution } \\
\text { pattern }\end{array}$ & $\begin{array}{l}\text { Color of } \\
\text { sclerotia }\end{array}$ & \\
\hline SLM1 & 8 & Irregular & Dark brown & Macro/micro & 9 & $\begin{array}{l}\text { Sub-central- } \\
\text { peripheral }\end{array}$ & Dark brown & Macro/micro & 8 & Irregular & Dark brown & Macro/micro \\
\hline SLM2 & 19 & Sub-central & Dark brown & Macro & 9 & Irregular & Dark brown & Macro/micro & 9 & Peripheral & Dark brown & Macro \\
\hline SLM3 & 8 & $\begin{array}{l}\text { Central-sub- } \\
\text { central }\end{array}$ & Dark brown & Macro/micro & 8 & Irregular & Dark brown & Macro/micro & 8 & Peripheral & Dark brown & Macro/micro \\
\hline BYL1 & 8 & Irregular & Dark brown & Macro/micro & 26 & Peripheral & Dark brown & Macro & 9 & $\begin{array}{l}\text { Sub- } \\
\text { central/peripheral }\end{array}$ & Dark brown & Micro \\
\hline BYL2 & 11 & Irregular & Dark brown & Macro & 8 & Subcentral/peripheral & Dark brown & Macro/micro & 9 & Peripheral & Dark brown & Macro/micro \\
\hline KLT & 9 & Irregular & Dark brown & Macro/micro & 11 & Peripheral & Dark brown & Macro & 7 & Peripheral & Dark brown & Macro/micro \\
\hline KRY & 8 & Irregular & Dark brown & Macro & 7 & Peripheral & Dark brown & Macro & 5 & Peripheral & Dark brown & Macro/micro \\
\hline PTI & - & - & - & - & - & - & - & - & - & - & - & - \\
\hline BLR & - & - & - & - & - & - & - & - & & - & - & - \\
\hline NGW & 18 & Irregular & Dark brown & Macro & 6 & Peripheral & Dark brown & Macro & 6 & Sub-central & Dark brown & Macro/micro \\
\hline
\end{tabular}


Table 3. Effect of photoperiod on sclerotia number of different Rhizoctonia solani isolates

\begin{tabular}{|c|c|c|c|c|}
\hline \multirow[t]{2}{*}{ Code isolate } & \multicolumn{3}{|c|}{ Number of sclerotia } & \multirow[t]{2}{*}{ Mean } \\
\hline & 24 h dark ${ }^{*}$ & 24 h light ${ }^{*}$ & 24 h dark/12 h light" & \\
\hline SLM1 & $16.00 \pm 4.00 \mathrm{~h}-\mathrm{j}$ & $26.67 \pm 7.23 \mathrm{gh}$ & $97.33 \pm 15.31 \mathrm{~b}$ & $46.67 \pm 39.26$ \\
\hline SLM2 & $2.33 \pm 0.581$ & $51.67 \pm 4.51 \mathrm{de}$ & $23.00 \pm 4.36 \mathrm{hi}$ & $25.67 \pm 21.69$ \\
\hline SLM3 & $37.00 \pm 2.00 \mathrm{fg}$ & $20.00 \pm 5.00 \mathrm{hi}$ & $95.00 \pm 6.56 \mathrm{~b}$ & $50.67 \pm 34.32$ \\
\hline BYL1 & $9.00 \pm 2.00 \mathrm{j}-1$ & $5.00 \pm 1.00 \mathrm{kl}$ & $52.33 \pm 14.47 \mathrm{de}$ & $22.11 \pm 23.88$ \\
\hline BYL2 & $25.00 \pm 4.58 \mathrm{hi}$ & $72.00 \pm 15.52 \mathrm{c}$ & $44.67 \pm 4.51$ ef & $47.22 \pm 22.11$ \\
\hline KLT & $24.33 \pm 5.13 \mathrm{hi}$ & $20.33 \pm 3.21 \mathrm{hi}$ & $52.00 \pm 11.27 \mathrm{de}$ & $32.22 \pm 16.25$ \\
\hline KRY & $9.00 \pm 2.00 \mathrm{j}-1$ & $15.33 \pm 2.89 \mathrm{j}-\mathrm{i}$ & $57.00 \pm 10.44 \mathrm{~d}$ & $27.11 \pm 23.25$ \\
\hline PTI & $0.00 \pm 0.001$ & $0.00 \pm 0.001$ & $0.00 \pm 0.001$ & $0.00 \pm 0.00$ \\
\hline BLR & $0.00 \pm 0.001$ & $0.00 \pm 0.001$ & $0.00 \pm 0.001$ & $0.00 \pm 0.00$ \\
\hline NGW & $19.00 \pm 5.57 \mathrm{~h}-\mathrm{j}$ & $39.00 \pm 2.65 \mathrm{f}$ & $181.67 \pm 8.96 \mathrm{a}$ & $79.89 \pm 77.02$ \\
\hline Mean & $14.17 \pm 0.00$ & $25.00 \pm 23.09$ & $60.30 \pm 52.77$ & $33.16 \pm 39.01(+)$ \\
\hline
\end{tabular}

Note: Results are expressed as the average of 3 determinations \pm 1 standard deviation. (+) showed interaction factor. *Values followed with same letter along the same row or column were not significantly different according to Fisher's LSD test $(P<0.05)$. LSD I $\times \mathrm{F}=$ 10.81

Table 4. Effect of photoperiod on sclerotia weight of different Rhizoctonia solani isolates

\begin{tabular}{|c|c|c|c|c|}
\hline \multirow[t]{2}{*}{ Code isolate } & \multicolumn{3}{|c|}{ Weight of sclerotia (mg) } & \multirow[t]{2}{*}{ Mean } \\
\hline & 24 h dark $^{*}$ & 24 h light ${ }^{*}$ & 24 h dark/12 h light ${ }^{*}$ & \\
\hline SLM1 & $8.74 \pm 1.63 \mathrm{kl}$ & $57.90 \pm 14.21 \mathrm{e}-\mathrm{g}$ & $53.97 \pm 14.28 \mathrm{f}-\mathrm{h}$ & $40.20 \pm 25.73$ \\
\hline SLM2 & $7.03 \pm 1.231$ & $71.80 \pm 18.63 \mathrm{~d}-\mathrm{f}$ & $114.13 \pm 33.09 \mathrm{bc}$ & $64.32 \pm 50.43$ \\
\hline SLM3 & $36.67 \pm 5.27 \mathrm{~g}-\mathrm{j}$ & $36.30 \pm 8.14 \mathrm{~g}-\mathrm{j}$ & $72.47 \pm 16.54 \mathrm{~d}-\mathrm{f}$ & $48.48 \pm 20.39$ \\
\hline BYL1 & $12.97 \pm 3.69 \mathrm{j}-1$ & $7.53 \pm 1.96 \mathrm{kl}$ & $41.77 \pm 11.64 \mathrm{~g}-\mathrm{i}$ & $20.76 \pm 17.09$ \\
\hline BYL2 & $8.90 \pm 10.38 \mathrm{kl}$ & $40.80 \pm 8.86 \mathrm{~g}-\mathrm{i}$ & $31.63 \pm 5.22 \mathrm{~h}-\mathrm{k}$ & $27.11 \pm 15.99$ \\
\hline KLT & $20.73 \pm 6.93$ i-1 & $36.57 \pm 6.29 \mathrm{~g}-\mathrm{j}$ & $110.37 \pm 28.73 \mathrm{bc}$ & $55.89 \pm 44.10$ \\
\hline KRY & $17.27 \pm 11.27 \mathrm{i}-1$ & $82.10 \pm 17.68 \mathrm{de}$ & $120.57 \pm 34.34 \mathrm{~b}$ & $73.31 \pm 49.49$ \\
\hline PTI & $0.00 \pm 0.001$ & $0.00 \pm 0.001$ & $0.00 \pm 0.001$ & $0.00 \pm 0.00$ \\
\hline BLR & $0.00 \pm 0.001$ & $0.00 \pm 0.001$ & $0.00 \pm 0.001$ & $0.00 \pm 0.00$ \\
\hline NGW & $7.20 \pm 1.81 \mathrm{kl}$ & $94.37 \pm 16.30 \mathrm{~cd}$ & $177.80 \pm 37.26 \mathrm{a}$ & $93.12 \pm 76.63$ \\
\hline Mean & $11.95 \pm 11.55$ & $42.74 \pm 33.95$ & $72.27 \pm 58.83$ & $42.32 \pm 46.48(+)$ \\
\hline
\end{tabular}

Note: Results are expressed as the average of 3 determinations \pm 1 standard deviation. (+) showed interaction factor. *Values followed with same letter along the same row or column were not significantly different according to Fisher's LSD test $(P<0.05)$. LSD I $\times$ F $=$ 24.54 .
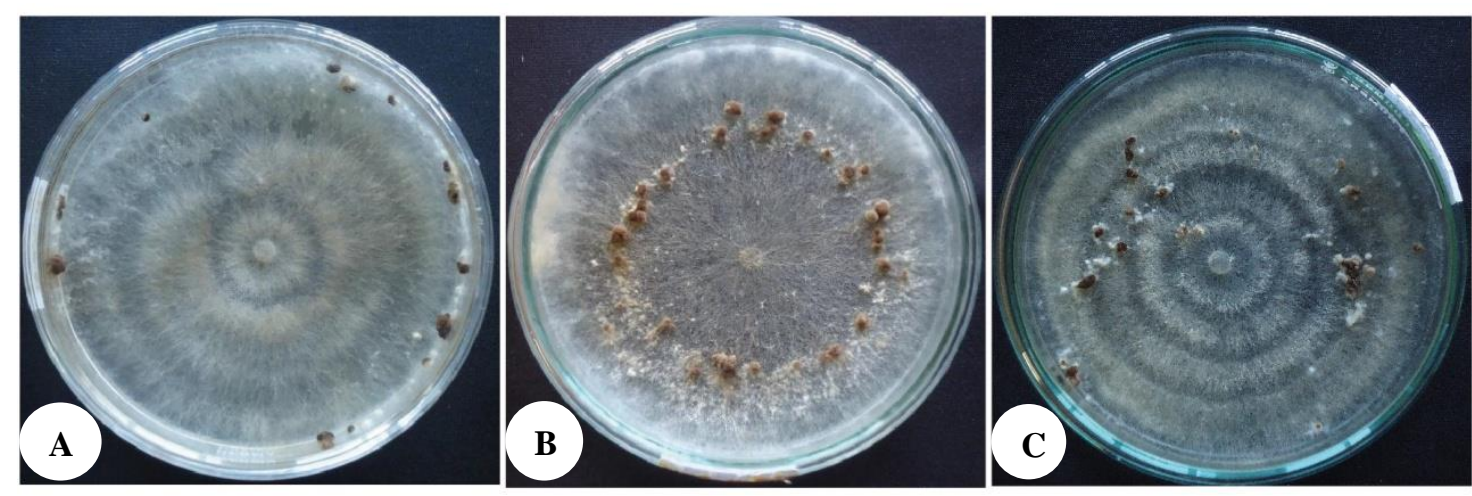

Figure 3. Sclerotial formation of Rhizoctonia solani isolates. A. Peripheral; B. Sub-central; C. Irregular 

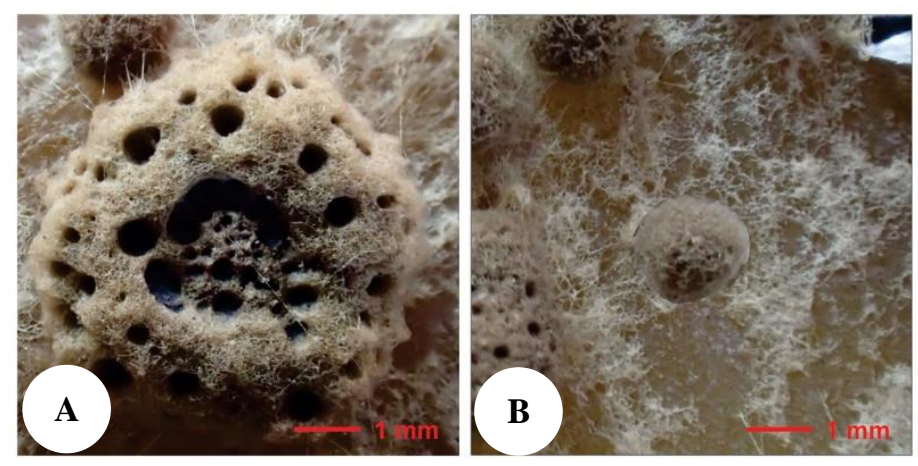

Figure 4. Sclerotial type of Rhizoctonia solani isolates. A. Macro sclerotia; B. Micro sclerotia
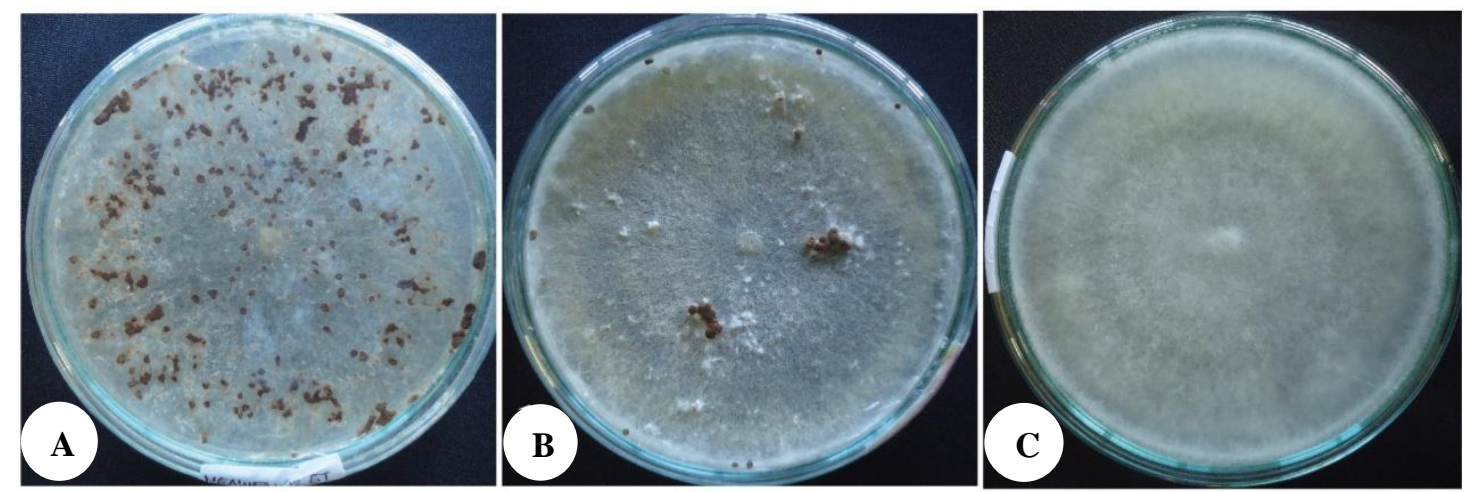

Figure 5. Sclerotial distribution of Rhizoctonia solani isolates. A. Abundant density of sclerotia; B. Low density of sclerotia; C. Absence of sclerotia

\section{Discussion}

Fungi use light as a signal to perceive and interact with their habitats (Idnurm and Heitmen 2005; Rangel et al. 2011). Light affects vegetative growth and fungal morphogenesis, thereby promoting conidiation and sclerotial development (Moromizato et al. 1983; Canessa et al. 2013). Light influences sclerotial formation and morphology; some isolates produce sclerotia in the light but not in the dark (Sumner 1996). The effects of light on the hyphal development and sclerotial formation of $R$. solani (AG-1, IA) have been studied by Moromizato et al. (1983). The variability of the cultural morphology of 10 $R$. solani isolates was studied based on mycelial and sclerotial characteristics under three different light conditions. The morphological parameters used in this investigation may be used to examine the ecobiology of $R$. solani isolates from other agro-climatic regions.

\section{Culture morphology characteristics \\ Radial growth}

Under the $24 \mathrm{~h}$ continuous light condition, nine maize isolates, and one rice isolate NGW needed 96-144 h to complete their radial growth. Similarly, under the $12 \mathrm{~h}$ alternating light/dark conditions required over $96 \mathrm{~h}$ to complete radial growth (96-168 h). By contrast, all isolates required $168-528 \mathrm{~h}$ to complete radial growth under the 24 h continuous dark condition. Lal and Khandari (2009) classified the growth rate of $R$. solani from rice into three groups, namely, fast, medium, and slow. Singh et al. (2014) found that $R$. solani isolates from maize showed faster colony growth compared to the rice isolates. Mishra et al. (2014b) showed five $R$. solani of maize isolates that grew fast under the $12 \mathrm{~h}$ alternating light/dark photoperiod and another four isolates that grew rapidly under $24 \mathrm{~h}$ continuous dark and light photoperiods. Similarly, Satyakala et al. (2017) reported that maximal growth of two fungi (T. harzianum and A. niger) occurs under $12 \mathrm{~h}$ alternating light/dark conditions. According to Juarez et al. (2000), incubating under 12- and 24-h photoperiods improved $R$. solani dry mass. Light, along with other external factors, acts as a signal triggering off various biophysical and biochemical processes, ultimately leading to morphological and phototrophic reactions (Chauhan and Gupta 2017). Also, light stimulates the sexual and asexual reproduction of fungi (Ferreira et al. 2015). Shahjahan et al. (1987) found a correlation between the mycelial growth of 10 isolates $R$. solani from the Philippines and their virulence to the host.

\section{Colony texture}

The colony texture showed variation under three different light conditions. The colony texture obtained 
under the $24 \mathrm{~h}$ continuous dark condition was cottony fluffy in most of the $R$. solani isolates. The maize isolates formed a cottony to cottony fluffy mycelium, whereas rice isolate showed cottony fluffy in all the three light conditions. This finding reveals that light exerts a direct effect on mycelial growth. Babitha et al. (2008) also reported that the Monascus purpureus colonies grown under total darkness showed a fluffy appearance to the colonies. Whereas, $R$. solani isolates revealed a fluffier mass of mycelia when cultured under the continuous light condition than when cultured under continuous dark and alternate light/dark conditions (Mishra et al. 2014b). Singh et al. (2014) reported that maize isolate form a compact dense to cottony mycelium, whereas rice isolates show sparse colonies.

\section{Colony color}

The cultures were classified into different groups based on colony pigmentation under three different light conditions. Under the $24 \mathrm{~h}$ continuous dark condition, nine maize isolates, and one rice isolate showed highly pigmented mycelia. This results suggested that the exposed to the darkness condition was most effective in inducing the pigment production. A significant difference in colony color was found between the colonies cultured in the continuous darkness than under the $12 \mathrm{~h}$ alternating light/dark and continuous light conditions exposure. This could be explained by postulating the existence of photoreceptors responsive to dark and light in this fungi (Babitha et al. 2008). Lal and Kandhari (2009) reported the variability of twenty-five $R$. solani isolates from rice as light brown, yellowish brown, whitish brown, dark brown, and very pale yellow. Sunder et al. (2003) showed that colony colors of $R$. solani ranged from brown, to light brown, dark brown, and yellowish brown. Fungal mycelia produce different types of pigmentation when exposed to light (Shrestha et al. 2006). The difference in color intensity may also correspond to the number of pigments released by each isolate in the culture medium (Debbarma and Dutta 2015). Reductions in pigmentation under light coincide with the reduction in the activity of tyrosine, which catalyzes melanization (Moromizato et al. 1983). Fungal pigmentation has been related to pathogenicity in some pathogenic fungi. Jacobson (2000) stated that pathogenic fungal isolates producing little or no melanin were less virulent or pathogenic compared with those producing large amounts of melanin. Kim et al. (2001) in their study, showed that melanization of mycelia of $R$. solani AG 1-IA is an important pathogenicity factor in rice. Aboellil and Mohammed (2011) mentioned that darkly pigmented isolate of $R$. solani was higher pathogenicity and virulence (rich-melanin content) than revealed by the hyaline isolate on $P$. vulgaris. Jiang et al. (2018) also reported that melanin contributes to virulence directly fungal antioxidant defense system in $R$. solani AG-1 IA.

\section{Growth pattern}

The distinct colony growth of abundant cottony mycelia growth was seen in $R$. solani isolates under light treatments. The isolates were categorized into two groups, i.e., abundant and moderate, based on their growth pattern. The growth pattern obtained under the $12 \mathrm{~h}$ light/dark condition was abundance in most of the $R$. solani isolates. Out of nine maize isolates, seven isolates, i.e., SLM1, SLM2, SLM3, BYL1, BYL2, KLT, and KRY and one rice isolate NGW showed abundant growth. It may be due to the inherent nature of these isolates to go for quick and profuse mycelial growth in early stages of growth before setting the sclerotia (Madhavi et al. 2015). Two isolates of $R$. solani showed abundant growth, one isolate showed moderate growth, and three isolates showed slight growth (Mishra et al. 2014b). Singh et al. (2014) and Debbarma and Dutta (2015) also grouped $R$. solani into three groups, i.e., high, medium, and low, based on its growth pattern.

\section{Sclerotial characteristics}

Time required for sclerotial formation

Light treatments also affect the initiation of sclerotia formation. There was a great diversity for the time taken for initiation of sclerotial formation in all three light conditions. Most of the $R$. solani isolates from maize and rice required a relatively faster time to produce sclerotia under the $12 \mathrm{~h}$ light/dark and continuous light conditions than continuous dark condition, except SLM1, BYL1, and KLT isolates, which grow faster under the $12 \mathrm{~h}$ light/dark and continuous dark conditions than continuous light condition. Akhtar et al. (2009) and Rajput and Harlapur (2016) reported that the times required for sclerotial initiation were 8-15 d and 7-15 d, respectively. Singh et al. (2014) observed that rice isolates were produced very quickly (3-4 days) in comparison with maize isolates (5-10 d) and the time required for sclerotial initiation was, at most, $25 \mathrm{~d}$. In general, sclerotial initiation was occurred faster in the $12 \mathrm{~h}$ light/dark condition than in the $24 \mathrm{~h}$ continuous dark or $24 \mathrm{~h}$ continuous light condition. Similarly, Mishra et al. (2014b) reported that initiation of sclerotia of $R$. solani was found to be dependent on the combination of light and dark conditions. Dutta et al. (2012) also reported that the maximum radial growth of $R$. solani isolates from maize was found in alternate lightdark. $R$. solani isolate required a relatively faster time to produce sclerotia under alternate light-dark and alternate dark-light conditions. Muthukumar and Venkatesh (2013) showed that $S$. rolfsii was exposed to $12 \mathrm{~h}$ light and $12 \mathrm{~h}$ darkness recorded more mycelial growth, number, and weight of sclerotia of $S$. rolfsii. These results indicated that light is essential for the mycelial growth and development of sclerotia of S. rolfsii. Patidar et al. (2017) in their study, found that white light was most suitable for radial growth and sclerotial formation of different isolates of $R$. solani. In contrast to the results reported by Moromizato et al. (1983), the sclerotia of two $R$ solani (AG-1, IA) isolates were formed early under continuous light irradiation than in the dark condition. Lokesha and Somashekar (1988) mentioned that the growth mycelia and sclerotia of $R$. solani grow faster with high number of sclerotia production occurred under visible light than darkness. Maurya et al. (2010) showed that dark and light conditions did not affect number of sclerotia of Sclerotium rolfsii. Patidar et al. (2017) also reported a variation in the number of sclerotia (43.33- 
57.00) was found in seven $R$. solani isolates from rice when incubated under $24 \mathrm{~h}$ continuous white light conditions. There are two distinct processes which control sclerotial development phases, namely, the formation of sclerotial initials, and sclerotial growth and maturation. This is quite apparent when a comparison is made between light- and dark- incubated cultures. Initials were apparent in lightgrown cultures and readily developed into mature sclerotia. Although initials were present in dark-incubated cultures, they did not develop into mature sclerotia. Therefore, light is essential for sclerotial development and subsequent maturation (Miller and Liberta 1976)

\section{Distribution pattern}

The distribution pattern of sclerotia of $10 R$. solani isolates showed variation under three different light conditions. Formation of sclerotia in petri dishes could be classified into five groups: peripheral, sub-central, centralsub-central, sub-central-peripheral, or irregular in all three light conditions. Most of the sclerotial formation of $R$. solani isolates was produced at peripheral in circular manner when exposed under the $12 \mathrm{~h}$ light/dark and continuous light conditions. The pattern of sclerotia production (central, peripheral, and scattered) has been recorded by Debbarma and Dutta (2015). Mishra et al. (2014b) reported classified sclerotial formation in maize into three groups, i.e., peripheral ring, scattered, and irregular. Moromizato (1983) revealed that determining the relationship between light exposure and sclerotial formation in fungi is difficult.

\section{Color and type of sclerotia}

All 10 isolates of $R$. solani from maize and rice under three different light treatments showed no variations in sclerotial color. Based on the pigmentation of the sclerotia, Rajput and Harlapur (2016) assigned maize isolates into three groups, namely, dark brown, brown, and red-brown. Variations in the sclerotial color of maize isolates from light brown to dark brown were also reported by Singh et al. (2014).

\section{Number and weight of sclerotia}

All 10 isolates of $R$. solani under three different light treatments showed variations in number and weight of sclerotia. Overall, more sclerotia were observed in the artificial $12 \mathrm{~h}$ alternating light/dark condition than in the 24 $\mathrm{h}$ continuous dark or $24 \mathrm{~h}$ continuous light condition. Most of the $R$. solani isolates from maize and rice showed a relatively abundant to produce sclerotia under the $12 \mathrm{~h}$ light/dark condition than continuous light and continuous dark conditions, except SLM2 and BYL2 isolates, which produce more under the continuous light condition than 12 $\mathrm{h}$ light/dark and continuous dark conditions. Mishra et al. (2014b) reported that alternate light/dark periods induce more sclerotia than do continuous light and dark periods. Heavier sclerotia were obtained in the artificial $12 \mathrm{~h}$ light/dark condition than in the $24 \mathrm{~h}$ continuous dark or continuous light condition. Mishra et al. (2014a) noted that the maximum and minimum weights of sclerotia are approximately $70 \mathrm{mg}$ (MRS11 and MRS19) and $4 \mathrm{mg}$
(MRMS17). Sclerotia play a significant role in the life cycle of $R$. solani, allowing it to survive under unfavorable environmental conditions. The sclerotial formation of $R$. solani is affected by environmental factors, such as nutrient supply, $\mathrm{pH}$, temperature, aeration, and light (Hu et al. 2017).

The finding in the present study indicates that $R$. solani isolates from different geographic locations react differently to these varying light conditions. All isolates revealed great diversity in cultural and morphological characteristics after exposure to three different light conditions. The cultural morphology variability was not related to the geographical origin of the isolates. Isolate's variation was not dependent on geographical location.

The ability of $R$. solani isolates to grow faster and produce more sclerotia under artificial $12 \mathrm{~h}$ alternating light/dark conditions may be a contributing factor in the dominance of these isolates over others in terms of causing disease. Madhavi et al. (2015) revealed that the behavior of the pathogen to grow quickly and produce sclerotia might increase the chances of the pathogen to survive in the next season. High sclerotial aggregation, though hinder in quick dispersal, helps in increasing the chances of germination because of the enhanced surface area. The management of BLSB disease is very difficult because the dispersal, propagation, and long-term survival of this pathogen is mediated through the sclerotium, a pigmented structure with many hyphae, which can remain quiescent for a long period under conditions that are unfavorable for vegetative growth (Abdel-Motaal et al. 2010). This information is important for future studies, especially those aiming to design control measures and strategies, e.g., cultural practices, breeding programs, and application of fungicides (Wahab et al. 2015; Widodo and Hidayat 2018). Successful execution of disease management programs, in addition to other factors, can be implemented depending on the understanding of the population structure of the pathogen and the mechanism by which variations arise within pathogen populations through detection of cultural and morphological characteristics (Ali et al. 2013; Masoodi et al. 2013).

These results indicated that the impact of grow faster and produce more sclerotia of $R$. solani induced by manipulation in the light periods. Under the $24 \mathrm{~h}$ dark condition was not found favorable for the vegetative growth and early initiation of sclerotia. Keeping all these in mind, our finding in this agriculturally important to understand the influence of light on the growth and sclerotial formation of pathogenic fungi, $R$. solani isolated from the field of Yogyakarta Special Region and Central Java, Indonesia under laboratory conditions.

In conclusions, all isolates revealed great diversity in cultural and morphological characteristics after exposure to three different light conditions. This result indicates that modification of the light duration exerts a great impact on some $R$. solani isolates. Compared with the results of exposure to $24 \mathrm{~h}$ continuous light and dark conditions, exposure to $12 \mathrm{~h}$ alternating light/dark conditions induced mycelial growth and early initiation of sclerotial formation in several $R$. solani isolates. This study is significant in 
understanding the role of light duration in differential behavior of mycelia growth and sclerotial development of $R$. solani isolates, to study further the host-pathogen relationship and disease development. Knowledge about the differential response of fungi to light and dark can be exploited to decrease disease severity by minishing pathogen inoculum through agricultural practices, e.g., plowing under of soil, using of mulches, wider row spacing, and soil cultivation. We hope that the results of this study help to reveal the factors regulating the pathogenicity of the fungus. Also, it might be useful for controlling the growth and development of this disease through manipulating cultural practices not favorable to the disease on the maize field in coming future.

\section{ACKNOWLEDGMENTS}

This work was supported by the Indonesian Agency for Agriculture and Development, Ministry of Agriculture of Republic Indonesia and Universitas Gadjah Mada (UGM) Yogyakarta, RTA Grant, 2019. The authors wish to thank the BPP UGM for help in language editing.

\section{REFERENCES}

Abdel-Motaal FF, El-zayat SA, Kosaka Y, El-Sayed MA, Kashima R, Maeda Y, Nassar MSM, Ito S. 2010. Antifungal activities of hyoscyamine and scopolamine against two major rice pathogens: Magnaporthe oryzae and Rhizoctonia solani. J Gen Plant Pathol 76:102-111.

Aboellil AH, Mohammed NM. 2011. Effect of some chemicals on growth, melanogenesis, pathogenicity and metabolic activities of Rhizoctonia solani. J Yeast Fungal Res 2:143-152.

Akhtar J, Jha VK, Kumar A, Lal HC. 2009. Occurrence of banded leaf and sheath blight of maize in Jharkhand with reference to diversity in Rhizoctonia solani. Asian J Agric Sci 1: 32-35.

Ali R, Khan H, Ahmad F, Ahmad N. 2013. Colony colour and texture of different isolates of Fusarium solani, the cause of root rot disease of okra. Asian J Agric Biol 1: 190-193.

Babitha S, Carvahlo JC, Soccol CR, Pandey A. 2008. Effect of light on growth, pigment production and culture morphology of Monascus purpureus in solid-state fermentation. World J Microbiol Biotechnol. DOI 10.1007/s11274-008-9794-3.

Bintang AS, Wibowo A, Priyatmojo A, Subandiyah S. 2017. Morphological and molecular characterization of Rhizoctonia solani isolates from two different rice varieties. J Perlindungan Tanaman Indonesia 21: 72-79. [Indonesian]

Canessa P, Schumacher J, Hevia MA, Tudzynski P, Larrondo LF. 2013. Assessing the effects of light on differentiation and virulence of the plant pathogen Botrytis cinerea: characterization of the White Collar Complex. PLoS ONE 8: e84223.

Chauhan P, Gupta D. 2017. Impact of varying light duration on radial growth of pink oyster mushroom. Int J Curr Microbiol App Sci 6: 368-371.

Dai TT, Xu Z, Zhou X, Li B, Mao SF. 2017. The inhibitory effect of the plant alkaloid camptothecin on the rice sheath blight pathogen Rhizoctonia solani. Int J Agric Biol 19: 558-562.

Debbarma M, Dutta P. 2015. Cultural and morphological variability in Rhizoctonia solani isolates of different hosts of Assam. Indian J App Res 5: 878-883.

Degli IF, Russo VE. 1984. Isolation of new white collar mutants of Neurospora crassa and studies on their behaviour in the blue lightinduced formation of photoperithecia. J Bacteriol 159: 757-761.

Djaenuddin N, Nonci N, Muis M. 2017. Effectiveness of the formula Bacillus subtilis TM4 in controlling maize diseases. J Fitopatol Indon 13: 113-118. [Indonesian]
Dutta U, Kalha CS, Srivastava JN. 2012. Effect of different light intensities, different light duration patterns and different temperatures on growth and sclerotial development of Rhizoctonia solani. Intl J Agric Sci 8: 184-187.

Ferreira ICPV, Sales NLP, de Araujo AV. 2015. Effect of temperature and photoperiod on the development of fusariosis in pineapples. Afr $\mathrm{J}$ Agric Res. 10: 76-83.

Gao J, Chen Z, Luo M, Peng H, Lin H, Qin C, Yuan G, Shen Y, Ding H, Zhao M, Pan G, Zhang Z. 2014. Genome expression profile analysis of the maize sheath in response to inoculation to $R$. solani. Mol Biol Rep 41: 2471-2483. DOI:10.1007/s11033-014-3103-z.

Hatakeyama R, Tomo YN, Yujiro H, Katsuhiko K. 2007. Light represses conidiation in koji mold Aspergillus oryzae. Biosci Biotechnol Biochem 71: 1844-1849.

Hooda KS, Khokhar MK, Parmar H, Gogoi R, Joshi D, Sharma SS, Yadav OP. 2015. Banded leaf and sheath blight of maize: historical perspectives, current status, and future directions. Proc Natl Acad Sci India Sect B Biol Sci 84: 1041-1052.

Hu W, Pan X, Abbas HMK, Li F, Dong W. 2017. Metabolites contributing to Rhizoctonia solani AG-1-IA maturation and sclerotial differentiation revealed by UPLC-QTOF-MS metabolomics. PLoS ONE 12: 1-16. DOI:1371/journal.pone.0177464.

Idnurm A, Heitmen J. 2005. Light controls growth and development via a conserved pathway in the fungal kingdom. PloS Biol 3: 0615-0626. DOI:10.1371/journal.pbio.0030095.g002.

Izhar T, Chakraborty M. 2013. Genetic analysis of banded leaf and sheath blight resistance (Rhizoctonia solani) in maize. J Pharmacogn Phytochem 1: 1-5.

Jacobson ES. 2000. Pathogenic roles for fungal melanins. Clin Microbiol Rev 13: 708-717.

Jiang S, Wang C, Shu C, Huang Y, Yang M, Zhou E. 2018. Effects of catechol on growth, antioxidant enzyme activities and melanin biosynthesis gene expression of Rhizoctonia solani AG-1 IA. Can J Plant Pathol 40: 220-228.

Juarez M, Juarez D, Russo VM. 2000. Growth and protein content in Colletotrichum circinas, Fusarium solani and Rhizoctonia solani in liquid culture. Biol Plantarium 43: 577-582.

Kim HT, Chung YR, Cho KY. 2001. Mycelial melanization of Rhizoctonia solani AG1 affecting pathogenicity in rice. Plant Pathol J 17: $210-215$.

Lin HJ, Tan DF, Zhang ZM, Lan H, Gao SB, Rong TZ, Pan GT. 2008. Analysis of digenic epistatic and QTL $\times$ environment interactions for resistance to banded leaf and sheath blight in maize (Zea mays). Int $\mathrm{J}$ Agri Biol 10: 605-611.

Lal M, Kandhari J. 2009. Cultural and morphological variability in Rhizoctonia solani isolates causing sheath blight of rice. J Mycol Pl Pathol 39: 77-81.

Lal M, Singh V, Kandhari J, Sharma P, Kumar V, Murti S. 2014. Diversity analysis of Rhizoctonia solani causing sheath blight of rice in India. Afr J Biotechnol 13: 4594-4605.

Lee L, Rosenstiel TN, Eppley SM. 2010. Variation of photoperiod response in moss gametangial formation. The Bryologist 113: 673678.

Lokesha S, Somashekar RK. 1988. Influence of light on growth pattern of Rhizoctonia solani-a maize isolate. Curr Sci 57: 614-615.

Madhavi M, Reddy PN, Reddy RR, Reddy SS. 2015. Morphological and molecular variability of Rhizoctonia solani isolates causing banded leaf and sheath blight in maize. Int $\mathbf{J}$ Bio-resource Stress Manag 6:375-385.

Masoodi L, Anwar A, Ahmed S, Sofi TA. 2013. Cultural, morphological and pathogenic variability in Colletotrichum capsici causing die-back and fruit rot of chili. Asian J Plant Pathol 7: 29-41.

Maurya S, Udar PS, Rashmi S, Amitabh S, Harikesh BS. 2010. Role of air and light in sclerotial development and basidiospore formation in Sclerotium rolfsii. J of Pl Prot Res 50: 206-209. DOI:10.2478/v10045-010-0035-z.

Miller RM, Liberta AE. 1976. The effect of light on acid-soluble polysaccharide accumulation in Sclerotium rolfsii Sacc. Sclerotium rolfsii Sacc. Can J Microbiol 22 (7): 967-70.

Miller RM, Liberta AE. 1977. The effects of light and tyrosine during sclerotia development in Sclerotium rolfsii Sacc. Can J Microbiol 23: 278-287.

Mishra PK, Gogoi R, Singh PK, Rai SN, Singode A, Kumar A, Manjunatha C. 2014a. Morpho-cultural and pathogenic variability in Rhizoctonia solani isolates from rice, maize and green gram. Indian Phytopath 67: 147-154. 
Mishra PK, Gogoi R, Singh PK, Rai SN, Kumar A. 2014b. Effect of photo period on morpho-cultural characteristics of Rhizoctonia solani f. sp. sasakii of maize. Ann Biol 30: 733-737.

Moromizato Z, Amano T, Tamori M. 1983. The effect of light on sclerotial formation of Rhizoctonia solani Kuhn (AG-1, IA). Ann Phytopath Soc Japan 49: 495-500.

Muis A, Pakki S, Nonci N. 2010. Major corn diseases in Palu Valley of Indonesia and their control. In: Zaidi PH, Azrai M, Pixley KV (eds.); Proceeding of the $10^{\text {th }}$ Asian Regional Maize. Makassar, 20-23 October 2008.

Muthukumar A, Venkatesh A. 2013. Effect of light and aeration on the growth of Sclerotium rolfsii in vitro. Afr J Biotechnol 12: 6843-6846.

Nuraini FR, Setyaningsih R, Susilowati A. 2017. Screening and characterization of endophytic fungi as antagonistic agents toward Fusarium oxysporum on eggplant (Solanum melongena). Biodiversitas 18: 1377-1384.

Patidar P, Awadhiya GK, Patil KP. 2017. Assessing the effects of varied temperature, $\mathrm{pH}$ and wave length of light on the growth and sclerotial formation of Rhizoctonia solani Kuhn. Agric Update 12: 1866-1973.

Priyatmojo A, Escopalao VE, Tangonan NG, Pascual CB, Suga H, Kageyama K, Hyakumachi M. 2001. Characterization of a new subgroup of Rhizoctonia solani anastomosis group 1 (AG-1-ID), causal agent of a necrotic leaf spot on coffee. Phytopathology 91: 1054-1061

Rajput LS, Harlapur SI. 2016. Cultural and morphological variability in Rhizoctonia solani causing banded leaf and sheath blight of maize. Indian J Plant Prot 44: 165-167.

Rangel DEN, Fernandes EKK, Braga GUL, Roberts DW. 2011. Visible light during mycelial growth and conidiation of Metarhizium robertsi produces conidia with increased stress tolerance. FEMS Microbiol Lett 315: 81-86.

Ritchie F, Bain RA, McQuilken MP. 2009. Effects of nutrient status, temperature, and $\mathrm{pH}$ on mycelial growth, sclerotial production and germination of Rhizoctonia solani from potato. J Plant Pathol 91: 589-596.

Satyakala K, Alladi A, Thakur KD. 2017. Effect of physiological parameters on growth of Aspergillus niger and Trichoderma harzianum. Int J Pure App Biosci 5: 1808-1812.

Shahjahan AKM, Fabellar N, Mew TW. 1987. Relationship between growth rate, sclerotia production, and virulence of isolates of Rhizoctonia solani Kuhn. IRRN 12: 28-29.

Sharma RC, Srinivas P, Basta BK. 2002. Banded leaf and sheath blight of maize - its epidemiology and management. In: Raj BNP, Ransom JK, Adhikari K, Palmer AFE (eds.); Proceedings of a Maize Symposium, pp: 108-112, Kathmandu (Nepal), 2-5 December 2001.
Shrestha B, Lee W, Han S, Sung J. 2006. Observations on some of the mycelial growth and pigmentation characteristics of Cordyceps militaris isolates. Mycobiology 34: 83-91.

Singh V, Kumar S, Lal M, Hooda KS. 2014. Cultural and morphological variability among Rhizoctonia solani isolates from trans-gangetic plains of India. Res Crops 15: 644-650.

Singh V, Amaradasa BS, Karjagi CG, Lakshman DK, Hooda KS, Kumar A. 2018. Morphological and molecular variability among Indian isolates of Rhizoctonia solani causing banded leaf and sheath blight in maize. Eur J Plant Pathol 152: 45-60.

Soenartiningsih, Harsoyo AT, Pusposenjoyo N, Baon JB. 2006. Pengaruh inokulasi jamur mikoriza arbuskular terhadap penyakit busuk pelepah pada jagung di lapangan. Biosfera 29: 30-35. [Indonesian]

Soenartiningsih. 2007. Pengendaliah Hayati Penyakit Busuk Pelepah (Rhizoctonia solani) pada Jagung dengan Jamur Mikoriza Arbuskular. [Dissertation]. Universitas Gadjah Mada, Yogyakarta. [Indonesian]

Soenartiningsih, Akil M, Andayani NN. 2015. Soil borne fungus (Rhizoctonia solani) the pathogen of sheath blight disease of maize and sorghum and its control measures. Iptek Tanaman Pangan 10: 8592. [Indonesian]

Sudjono MS. 1995. Effectiveness of antagonists against sheath blight and ear rot caused by Rhizoctonia solani Kuhn. Prosiding Kongres Nasional XII dan Seminar Ilmiah Perhimpunan Fitopatologi Indonesia. Yogyakarta, 6-8 September 1993. [Indonesian]

Sumner DR. 1996. Sclerotia formation by Rhizoctonia species and their survival. In: Sneh B, Jabaji-Hare S, Neate S, Dijst G (eds) Rhizoctonia Species: Taxonomy, Molecular Biology, Ecology, Pathology and Disease Control. Kluwer Academic Press, The Netherlands.

Sunder B, Kataria HR, Satyavir, Sheoran OP. 2003. Characterization of Rhizoctonia solani associated with root/collar rots and blights. Indian Phytopath 56: 27-33.

Wahab MZA, Sijam K, Ismail R, Hashim M, Hata E, Zulperi D. 2015. Phenotypic characterization and molecular identification of Malaysian Pseudomonas fuscovaginae isolated from rice plants. Asian J Plant Pathol 9: 112-123.

Widodo, Hidayat SH. 2018. Identification of Colletotrichum species associated with chili anthracnose in Indonesia by morphological characteristics and species-specific primers. Asian J Plant Pathol 12: 7-15.

Zhou S, Liu Y, Zhang M, Li B, Chen X, Liang W. 2016. Comparison of the virulence and cognate virulence factors of multinucleate, binucleate and uninucleate Rhizoctonia isolates, causing sheath blight on maize plants. Eur J Plant Pathol 145: 501-506. 